\title{
Labor Movements, Mainly in Eastern Europe
}

\author{
Harald Kleinschmidt
}

Professor em. Dr. phil. habil. Tokyo, Japan; Senior Fellow, Alfried Krupp Wissenschaftskolleg, Greifswald, Germany

\begin{abstract}
The main factors of labor movements, mainly in Eastern Europe, are considered in this paper. The influence of economic indicators and peculiarities of economic development of the countries of the region in the current migration situation in Europe as a whole has been studied. The analysis of the migration policy of the countries of the European Union and individual countries is performed. The main tendencies of migration flows of the population in the region and separate countries of Eastern Europe are revealed. General migration problems as an integrational form of the existence of modern economies of the countries are summarized.
\end{abstract}

Keywords: labor movements, Eastern Europe, migration.

JEL Classification: J6.

(C) The Author, 2017. This article is published with open access at ARMG Publishing.

\section{Introduction}

In the following review of recent labor movements in East Central Europe, I intend to examine some current arguments regarding motivations for and potential consequences of large-scale international migration. Since 2015, the debate about migration within as well as into Europe has triggered a great deal of alarmism. For one, Ivan Krastev paints a gloomy picture about the future of the European Union, arguing that Eastern European states are facing mass emigration of the economically achieving parts of their societies, leaving behind the aged and the poor. Thus, he supposes that 2.5 million migrants have left Poland since 1989, that 3.5 million migrants have left Romania since 1989, that the total population of Lithuania has shrunk from 3.5 million to 2.9 million, that every tenth Bulgarian national has emigrated since 1989 , a loss of population of $27 \%$ to be estimated by 2050 [22]. In the same vein, Olga Oleinikova assumes that 2,537,400 emigrants moved out of Ukraine between 1991 and 2004, of them 1,897,560 to post-Soviet states and 639,900 to "Western" states [37, 50, 51], whereas Olena Malynovska expects a decline of the Ukrainian population from 44.72 million in 2016 to 32.9 million by 2050 [36]. At the height of the so-called "Refugee Crisis" (2015-2016), the Polish Prime Minister claimed on 12 January 2016 that Poland was then hosting about one million "refugees" from Ukraine, with the Ukrainian ambassador to Poland immediately rejecting the figure [14]. While the Polish government, apparently, has not restated its claim, Bloomberg News, as late as on 7 March 2017, again reported slightly less than one million Ukrainians in Poland in 2016, expected 1.3 million for 2017 and added the estimate that Poland will need further five million workers with the next twenty years to maintain economic growth [9]. However, the entire series of alarming news began with an official British statement by the Office for National Statistics, presenting a list of what they term "usual residents" (i.e., persons residing at the place of their enumeration) in the UK but born outside the UK. Immigrants from Poland reportedly topped the list at 831,000 persons and were followed by immigrants from India at 795,000, from Pakistan at 503,000 and from Ireland at 382,000 persons [35].

Against the backdrop of general social-science migration studies, such alarmism is a common and wellknown but an unwarranted feature. For one, the reported statistics have focused on unidirectional migration, that is, emigration from states in Eastern Europe; by contrast, since the late nineteenth century, migration research has shown that migration is usually a reciprocal process in the sense that movements in one direction are most commonly accompanied by contemporaneous movements in the opposite direction [12-13]. The implications are, first, that emigration statistics alone hardly ever tell the full story, whence they have to be filled up with immigration data, and, second, that long-recorded remigration processes have to be taken into account ${ }^{1}$. A methodological problem adds to the difficulty of interpreting migration data. The problem has emerged from the practice of collecting demographic data through state agencies that have been estab-

\footnotetext{
${ }^{1}$ For studies on early cases of remigration see David Cressy (1987), Daniel Statt (1995). For a bibliographical survey see Frank Bovenkerk $(1974 ; 1975)$.
} 
lished since the early nineteenth century ${ }^{1}$. These state agencies have followed their own migration definitions. By implication, each state statistical agency presents data that are hardly ever compatible with those collected by agencies in other states. the consequence is that migration data have been state-centric and are usually not comparable at cross-country levels. Put differently, migration data from one state are hardly ever match migration data from another state ${ }^{2}$. Any reasonable study of movements of people across international borders of states, therefore, cannot focus on bilateral relations between states alone, but must contextualise migration processes.

The lack of consistency and compatibility of migration data becomes immediately evident once the figures relevant to Eastern Europe become subject to close scrutiny. First and foremost, it is exceedingly rare for official statistical bureaus to generate public sentiment regarding a certain population group. Hence, the information that immigration from Poland to the UK should have become larger than immigration from South Asia was released with demonstrative publicity on the part of British national statistics, and this is an unprecedented occurrence, which cannot be disentangled from the public debate on immigration in the UK in the run-up to and the aftermath of the Brexit referendum. Second, further data available from British National Statistics for 2004, 2008, 2014, 2015 and 2016 do not substantiate the British statement regard immigration from Poland. The relevant figures, provided by the British government, relate to migration from and to EU 8 (Czech Republic, Estonia, Hungary, Latvia, Lithuania, Poland, Slovakia, Slovenia) [48].

Table 1. The net gain of migration from EU 8 states into the UK during 2004-2016

\begin{tabular}{|l|l|l|l|}
\hline 2004 & $\begin{array}{l}\text { in-migration to the UK: } \\
53,000 ; \\
\text { out-migration from the UK: } \\
3,000 ; \\
\text { net gain } 50,000 .\end{array}$ & $\begin{array}{l}\text { in-migration to the UK: } \\
89,000 ; \\
\text { out-migration from the UK: } \\
69,000 ; \\
\text { net gain: } 20,000 .\end{array}$ \\
\hline \multirow{3}{*}{2014} & $\begin{array}{l}\text { in-migration to the UK: } \\
80,000 ; \\
\text { out-migration from the UK: } \\
32,000 ; \\
\text { net gain: } 48,000 .\end{array}$ & $\begin{array}{l}\text { in-migration to the UK: } \\
73,000 ; \\
\text { out-migration from the UK: } \\
27,000 ; \\
\text { net gain: } 46,000 .\end{array}$ \\
\hline 2016 & $\begin{array}{l}\text { in-migration to the UK: } \\
48,000 ; \\
\text { out-migration from the UK: } \\
43,000 ; \\
\text { net gain 5,000. }\end{array}$ & & \\
\hline
\end{tabular}

The figures show that the net gain of migration from EU 8 states into the UK during a period of twelve years, which is the only figure comparable to numbers of residents, did not come in any way close to the figure given in 2015 for immigration from Poland alone. Moreover, the figures document a constant decline of the net gain to 2015 and the plummeting of the net gain in 2016, most likely due to the public debate about and the result of the Brexit referendum. Third, British immigration figures are by no means unique within a European context, as the following data on migration into the EU show (without specifying net gains or losses). The data have persistently featured higher immigration figures for Germany than for the UK, even though the UK has traditionally experienced high immigration rates from Commonwealth states [15].

Table 2. Migration in particular European countries in 2006-2015

\begin{tabular}{|l|c|c|c|c|}
\hline & 2006 & 2012 & 2014 & 2015 \\
\hline Poland & 10,802 & 217,546 & 222,275 & 218,147 \\
\hline Germany & 661,855 & 592,175 & 884,893 & $1,543,848$ \\
\hline UK & 529,008 & 498,040 & 631,991 & 631,452 \\
\hline France & 301,544 & 327,431 & 339,902 & 363,869 \\
\hline
\end{tabular}

\footnotetext{
${ }^{1}$ For early references to statistical bureaus and societies see Johann Nepumuk Zizius (1810), Wilhelm Ernst August von Schlieben (1830; 1839), Johann Gottfried Hoffmann (1840), Josef Edmund Woerl (1841), J. v. W. (1846), August Meitzen (1886; 1891; 1903; 2003).

${ }^{2}$ For the implications of the lack of compatibility of migration data on migration policy-making see Martin Baldwin-Edwards and Martin A. Schain (1994), Robin Cohen and Zig Layton-Henry (1997), Daniel Kubat (1993), Josef Schmid (1995), Hania Zlotnik (1987), Aristide R. Zolberg (1981).
} 
The figures for the UK reveal a discrepancy against British national statistics listing more immigrants from India alone than the EU data report for immigration to the UK from all non-EU states in 2015, and this discrepancy is difficult to account for only on the ground that the British government applies the UNDP definition of international migration ${ }^{1}$, whereas the EU has its own, and even if it is taken into account that British National Statistics referred to the total number of foreigners as "usual residents" in the UK and not just to people having arrived in 2015.

Regarding other EU states, the figures for Poland indicate that there has been a significant increase of inmigration since 2012, whence the gloomy picture of East European states dramatically thinning out their populations is not supported by statistics. For instance, in 2015, 132,387 people emigrated from Germany to Poland (compared to 195,666 in-migrants to Germany from Poland during the same year, the German net gain during this year being 63,479), with approximately 1.5 million people having left Germany between 2006 and 2016 [47]. Moreover, the total number of immigrants to Poland from non-EU states in 2015 is far lower than the number of "refugees" claimed to have arrived in Poland from Ukraine only during the same year. Third, the EU data receive support from Polish statistics relating to the numbers of Ukrainian "refugees" (respectively "asylum-seekers") officially recognised by the Polish government [24].

Table 3. Asylum-seekers from Ukraine in Poland

\begin{tabular}{|l|c|c|c|c|}
\hline & 2013 & 2014 & 2015 & 2016 \\
\hline Accepted & 15 & 17 & 32 & 96 (to July) \\
\hline Applications & 46 & 2318 & 2305 & 709 (to July) \\
\hline
\end{tabular}

These numbers document the exceedingly small number of persons residing in Poland on the legal basis of the Geneva Convention on the Status of Refugees of 1951. By implication, the by far largest number of immigrants from Ukraine to Poland has statuses other than that of a "refugee" or "asylum-seeker". Fourth, studies on migration relating to Poland have shown that about 905,200 Ukrainians were registered in the EU at large in 2015, of whom 336,000 persons resided in Poland. The number is the largest for any single EU member state but includes all Ukrainian residents registered in Poland in that year, not just people having arrived there in that year; the second largest expatriate Ukrainian community being in Italy and comprising some 238,000 persons [36: 11]. Apparently, the figure of one million people of Ukrainian origin in Poland in 2015 did not relate to immigration data; instead, it was drawn on the number of short-term visas issued to Ukrainian citizens by Polish government agencies during that year, in which the largest number of people moving from Ukraine to Poland did not several times. Therefore, the argument is unwarranted that "refugees" from Ukraine should have taken positions vacated by emigrants from Poland to the UK through replacement migration².

The conclusion is that Ukrainian in-migration into the EU has not been exceptional in the sense of representing movements of "refugees"; instead, it appears to have followed common migration patterns and portrays Ukrainian migrants as people in pursuit of livelihood strategies. This conclusion receives further support from data provided by the International Organization for Migration (IOM) listing numbers of long- and short-term migrant workers from Ukraine according to employment sectors. In 2014-2015, there were 424,000 long-term migrant workers from Ukraine, their main destinations being Russia (81,362 persons), Poland (95,346 persons) and the Czech Republic (77,548 persons), compared to 264,000 short-term migrant workers, their main destinations being Russia (123,464 persons), Poland (45,737 persons) and the Czech Republic (25,380 persons). Their main employment sectors were [36: 13]:

\footnotetext{
${ }^{1}$ The UN defines an international migrant as a person crossing an international border and residing in the host state for at le ast one year. On migration definitions see Donald J. Bogue (1959), Gérard Chaliand et al. (1994), Roland B. Dixon et al. (1937), Guy S. Goodwin-Gill (1978). International Labor Office (1922). Edgar Kant (1953), Joseph Mangalam (1968), Mangalam and Henry K. Schwartzweller (1970), Philip Martin (1993), Franz Nuscheler (1995), Nina Glick Schiller et al. (1995), Walter Schweitzer (1978), Graziano Tassello (1987), Wolfgang Weidlich and Günter Haag (1988).

2 This argument is mainly based on indirect evidence from UK Population Census data [[https://www.ons.gov.uk/peoplepopulationandcommunity/populationandmigration/internationalmigration/underlyingdatasheetsf orpopulationbycountryofbirthandnationalityjan11todec11; visited 10 August 2017], featuring, in comparison to numbers of immigrants from Poland, exceedingly low numbers of Ukrainians born in Ukraine but residing in the UK (estimated at c. 19,000 persons in 2011).
} 
Table 4. Employment sectors, 2014-2015 (in \%)

\begin{tabular}{|l|c|c|}
\hline \multicolumn{2}{|c|}{ Employment sectors, 2014-2015 (in \%) } \\
\hline Agriculture & Long term & Short term \\
\hline Construction & 11 & 45 \\
\hline Hotels, tourism & 37 & 8 \\
\hline Manufacturing & 5 & 12 \\
\hline Transport & 7 & 7 \\
\hline Health & 5 & 2 \\
\hline Trade & 3 & 5 \\
\hline Domestic help & 3 & 12 \\
\hline Others & 9 & 6 \\
\hline
\end{tabular}

The striking feature in these IOM data is the unusually high figure for "Others" being the second largest in the set for long-term migrants. This category must include the highly skilled people otherwise not specified in the set. The set appears to reflect IOM data collecting procedures in so far, as they prioritise low-skilled professions as employment sectors accommodating migrant workers. The conventional logic informing these procedures, thus, is "push-and pull", namely the expectation that out-migrating workers are poor people seeking employment at wealthier destinations ${ }^{1}$. But this expectation is far from obvious and has usually been gleaned from statistical inference rather than on information obtained from migrants themselves. While the logic of "push and pull" may apply to some migrant workers, it does not apply to all, as migration hump theory has suggested since the 1970s. Accordingly, further studies have long shown that the proportional numbers of highly skilled migrants motivated by the pursuit of livelihood strategies, that is, by factors other than the search for better employment opportunities, have long been high $^{2}$. In this context, then, migration in Eastern European states, EU member-states together with associated states, appears as a regular process, more often than not conforming to processes to be encountered elsewhere in Europe. There is thus little empirical support for alarmism with regard to Eastern European migration.

\section{Conclusions}

So, Eastern Europe for a long time remained a region of supply of labor resources to countries in Western Europe. Due to the high level of unemployment, the difference in levels of economic development and the significant differentiation of incomes between the countries of Eastern Europe and the countries of Western Europe, outflow of economically active population was observed. The current migration situation in the states of the region is heterogeneous. Social, economic and the political changes taking place in the region have changed the migration status of the countries of Eastern Europe. Significant reduction and aging of population in the countries of Eastern Europe caused by a high level of emigration, led to a shortage of labor resources. The processes of European integration and new migration policy associated with them had a special influence on the change of migration status. In the region, emigration is dominant in comparison with immigration, which is due to instability in the socio-economic development of countries, which requires further scientific study.

\section{References}

1. Aristide R. Zolberg (1981). International Migration in Political Perspective. In: Mary M. Kritz, Charles B. Keely and Silvano M. Tomasi (eds.). Global Trends in Migration. Staten Island, NY: Center for Migration Studies, pp. 3-27.

2. August Meitzen (1886, 1891, 1903, 2003). Geschichte, Theorie und Technik der Statistik (Berlin: Hertz, 1886), pp. 25-30 [second edn (Stuttgart and Berlin, 1903); reprint of the second edn (Saarbrüclen: Müller, 2003); English version (Philadelphia: American Academy, 1891)].

\footnotetext{
${ }^{1}$ For criticisms of the "Push-and-pull" model see Oscar Handlin (1951; ibid., 1973), Khalid Koser (2007), Russell King (1993), Michael Marrus (1990), P. Neal Ritchey (1976), Maja Zwick (2015).

${ }^{2}$ For references to livelihood strategies see Wilbur Zelinsky (1971), Philip L. Martin and J. Edward Taylor (1996), Commission on Human Security (2003), Peter Stalker (2001, 2008). Since the 1970s, international student mobility has been rather stable at about $10 \%$ of the entire student body, which means that the number of internationally mobile students has increased proportionately to the increase in the total student population. For studies of the migration of highly skilled people see Barbara Rhode (1993), Ulrich Teichler (2007).
} 
3. Barbara Rhode (1993). Brain Drain, Brain Gain, Brain Waste. Reflections on the Emigration of Highly Educated and Scientific Personnel from Eastern Europe. In: Russell King (ed.). The New Geography of European Migrations. London: Belhaven Press, pp. 228-245.

4. Commission on Human Security (2003). Human Security Now. New York: The Commission, p. 44.

5. Daniel Kubat (ed.). (1993). The Politics of Migration Policies. second edn. New York: Center for Migration Studies, first published (ibid., 1979).

6. Daniel Statt (1995). Foreigners and Englishmen. The Controversy over Immigration and Population. 1660-1760. Newark, DE, pp. 121-165.

7. David Cressy (1987). Coming Over. Migration and Communication between England and New England in the Seventeenth Century. Cambridge: Cambridge University Press, pp. 178-212.

8. Donald J. Bogue (1959). International Migration. In: Philip Morris Hauser and Otis D. Duncan (eds.). The Study of Population. Chicago: University of Chicago Press, pp. 486-509.

9. Dorota Bartyzel (2017). Poland Can't Get Enough of Ukrainian Migrants. Bloomberg News (7 March 2017). Available at https://www.bloomberg.com/news/articles/2017-03-06/. Accessed 10 August 2017.

10. Edgar Kant (1953). Migrationernes klassifikation och problematic. In: Svensk geografisk Arsbok, 29, 180-209.

11. Joseph Mangalam (1968). General Theory in the Study of Migration. In: International Migration Review, 2, 3-18.

12. Ernst Georg Ravenstein (1876). Census of the British Isles 1871, Birthplaces and Migration. In: Geographical Magazine, 3, 173-177, 201-206; Laws of Migration, in: Journal of the Royal Statistical Society, 49 (1885), 167-225, 52 (1889), 214-301.

13. Ernst Georg Ravenstein (1876). Laws of Migration. Counties and General. In: Geographical Magazine 3, 229-233; also in: Ravenstein, The Laws of Migration. New York (1987).

14. EURACTIV (21 January 2016). Available at https://www.euractiv.com/section/Europe-s-east/news/. Accessed 10 August 2017.

15. Eurostat (EU). Available at ec.europa.eu/Eurostat/statistics-explained/index.php/. Accessed 10 August 2017.

16. Frank Bovenkerk (1974). The Sociology of Return Migration. Publications of the Research Group for European Migration Problems, 20. The Hague: Nijhoff and Dordrecht: Springer.

17. Franz Nuscheler $(1995,2012)$. Internationale Migration, Flucht und Asyl. Grundwissen Politik, 14. Opladen: Leske + Budrich, pp. 27-31; reprint: Wiesbaden: Verlag für Sozialwissenschaft.

18. Gérard Chaliand, Michel Jan and Jean-Pierre Rageau (1994). Atlas historique des migrations. Paris: Éditions du Seuil.

19. Graziano Tassello, ed., Lessico migratorio (Rome: Centro Studi Emigrazione, 1987).

20. Guy S. Goodwin-Gill, International Law and the Movement of Persons between States (Oxford: Clarendon Press, 1978). International Labor Office, ed., Methods of Compiling Emigration and Immigration Statistics (Geneva: ILO, 1922).

21. Hania Zlotnik, "The Concept of International Migration as Reflected in Data Collection Systems", in: International Migration Review 21 (1987), pp. 925-945.

22. Ivan Krastev (2017). Europadämmerung (Berlin: Suhrkamp, 2017) [first published s. t.: After Europe (2017)].

23. J. v. W. (1846). Die Errichtung statistischer Bureaus und statistischer Privatvereine. In: Deutsche Vierteljahrs-Schrift, 3, pp. 95-128.

24. Joanna Fomina (2017). Economic Migration of Ukrainians to the European Union. A View from Poland. In: Agnieszka Pikenlizka-Wilczewska and Greta Uehling (eds.). Migration and the Ukraine Crisis 2016. Bristol: E-International Relations, pp. 78-89.

25. Johann Gottfried Hoffmann (1840). Lehre von den Steuern. Berlin: Verlag der Nicolaischen Buchhandlung, p. 4.

26. Josef Edmund Woerl (1841). Erläuterung zur Theorie der Statistik in näherer Rücksicht für Staatszwecke. Freiburg: Herder, pp. 32-60.

27. Johann Nepumuk Zizius (1810). Theoretische Vorbereitung und Einleitung zur Statistik. Vienna and Triest: Geistinger, pp. 69-71 [new edn, edited by Franz Kerschbaumer (Vienna and Triest: Geistinger, 1827)].

28. Josef Schmid (1995). Population Development Models as Criteria for Migration Policies?” In: Friedrich Heckmann and Wolfgang Bosswick, (eds). Migration Policies. A Comparative Perspective. Stuttgart: Enke, pp. 211-220. 
29. Khalid Koser (2007). Refugees, Transnationalism and the State. In: Journal of Ethnic and Migration Studies, 12, 233-254.

30. Russell King (1993). Why do People Migrate? The Geography of Departure. In: King (ed.). The New Geography of European Migrations. London: Belhaven Press, pp. 17-46.

31. Mangalam and Henry K. Schwartzweller (1970). Some Theoretical Guidelines Toward a Sociology of Migration. International Migration Review, 4, pp. 5-21; reprinted in: Kenneth C. W. Kammeyer (1975, ed.), Population Studies. Chicago: Rand McNally, pp. 173-187.

32. Martin Baldwin-Edwards and Martin A. Schain (eds) (1994). The Politics of Immigration in Western Europe. London: Cass.

33. Michael Marrus (1990). The Uprooted. An Historical Perspective. In: Göran Rystad (ed.). The Uprooted. Forced Migration as an International Problem in the Postwar Era. Lund: Lund University Press, pp. 47-57.

34. Nina Glick Schiller, Linda Basch and Christine Blanc-Szanton (1995). From Immigrant to Transmigrant. Theorizing Transnational Migration. Anthropological Quarterly, 68, 48-63.

35. Office for National Statistics for 2015. Available at https://www.ons.gov.uk/peoplepopulationandcommunity/populationandmigration/internationalmigration /bulletins/; reported by the BBC on 25 August 2016. Available at www.bbc.com/news/uk-politics37183733. Accessed 10 August 2017.

36. Olena Malynovska (2016). Migration in Ukraine. International organization for Migration (IOM).

37. Olga Oleinikova (2017). Moving out of 'Their Places'. 1991-2016. Migration of Ukrainians to Australia. In: Agnieszka Pikenlizka-Wilczewska and Greta Uehling (eds). Migration and the Ukraine Crisis 2016 (Bristol: E-International Relations), pp. 90-104.

38. Oscar Handlin $(1951,1973)$. The Uprooted. The Epic Story of the Great Migrations That Made the American People. Boston: Little, Brown and Co.; second edn (ibid.).

39. P. Neal Ritchey (1976). Explanations of Migration. In: Annual Review of Sociology, 2, pp. 363-404.

40. Maja Zwick (2015). Transnationale Migration. Eine dauerhafte Perspektive. Saharauische Flüchtlinge zwischen agency und vulnerability. In: Peripherie, 138/139, pp. 260-280.

41. Peter Stalker $(2001,2008)$. The No-Nonsense Guide to International Migration. Oxford: The New Internationalist, esp. at pp. 20-39, 129; second edn (Toronto: New International Publications, 2008).

42. Philip L. Martin and J. Edward Taylor (1996). The Anatomy of Migration Hump. In: Taylor (ed.). Development Strategy, Employment and Migration. Paris: OECD, pp. 43-62.

43. Philip Martin (1993). The Migration Issue. In: Russell King (ed.). The New Geography of European Migrations. London: Belhaven Press, pp. 1-16.

44. Philip Martin (1975) reprinted in: Kenneth C. W. Kammeyer (ed.). Population Studies. Chicago: Rand McNally, pp. 173-187.

45. Robin Cohen and Zig Layton-Henry (eds.) (1997). The Politics of Migration. Cheltenham and Brookfield, VT: Elgar.

46. Roland B. Dixon, Louis Halphen and Imre Ferenczi (1937). Migrations. In: Edwin Robert Anderson Seligman (ed.). Encyclopaedia of the Social Sciences, 10. New York: Macmillan, pp. 420-441.

47. Statista. https://de.statista.com/statistic.daten/. Accessed 10 August 2017.

48. UK Office for National Statistics. https://www.ons.gov.uk/peoplepopulationandcommunity/ populationandmigration/internationalmigration. Accessed 10 August 2017.

49. Ulrich Teichler (2007). Die Internationalisierung der Hochschulen. Frankfurt and New York: Campus. pp. 63-104.

50. Vladimir Grečić (1993). Mass Migration from Eastern Europe. A Challenge to the West? In: Russell King (ed.). The New Geography of European Migrations. London: Belhaven Press, pp. 135-151.

51. Volodymyr Evtoukh (1995). Contemporary Migrations in the Ukraine. In: Friedrich Heckmann and Wolfgang Bosswick (eds.). Migration Policies. A Comparative Perspective. Stuttgart: Enke, pp. 243-248.

52. Walter Schweitzer (1978). Modelle zur Erfassung von Wanderungsbewegungen. Schriften zur wirtschaftswissenschaftlichen Forschung, 129. Meisenheim: Hain.

53. Wilbur Zelinsky (1971). The Hypothesis of the Mobility Transition. In: Geographical Review, 61, pp. 219-249.

54. Wilhelm Ernst August von Schlieben (1830, 1839). Ansichten über Zweck und Einrichtung statistischer Sammlungen und Bureaus. Halle: Anton and Gelbcke. London Statistical Society, "Introduction". In: Journal of the London Statistical Society, 1, pp. 1-5.

55. Wolfgang Weidlich and Günter Haag (eds.). (1988). Interregional Migration. Dynamic Theory and Comparative Analysis. Berlin, London, New York, Paris and Tokyo: Springer, pp. 9-11. 